\title{
Research knowledge and meaningful learning: a journey through Teacher education
}

\section{Saberes da pesquisa e aprendizagem significativa: um percurso pela formação de professores}

\section{Conocimiento de investigación y aprendizaje significativo: um caminho para la formación de profesores}

\author{
Aureliano Oliveira Alves ${ }^{1}$ (i), Ivoneide Pinheiro de Lima $^{2}$ iD , Joselma Ferreira Lima e Silva $^{3}$ (D) \\ ${ }^{1}$ State University of Ceará, Limoeiro do Norte, Ceará, Brazil. \\ ${ }^{2}$ State University of Ceará, Fortaleza, Ceará, Brazil. \\ ${ }^{3}$ Federal Institute of Education, Science and Technology of Piauí, Piripiri, Piauí, Brazil. \\ Corresponding author: \\ Aureliano Oliveira Alves \\ Email: aureliano.oliveira@uece.br
}

How to cite: Alves, A. O., Lima, I. P., \& Lima e Silva, J. F. (2021). Research knowledge and meaningful learning: a journey through Teacher education. Revista Tempos e Espaços em Educação, 14(33), e16278.

http://dx.doi.org/10.20952/revtee.v14i33.16278

\section{ABSTRACT}

The article brings discussions about the knowledge of research in the continuing education of teachers of Mathematics for Meaningful Learning. This is a literature review that raised the following question for the construction of the State of the Question: what has already been produced academically about the contributions of research practice to the development of meaningful learning, considering the pedagogical practice of the Mathematics teacher at 6th year, in his/her continuing education? This aimed to map what exists of scientific production on Research Knowledge in the continuing education of Mathematics teachers for Meaningful Learning. For searches in the databases we applied the 2000-2021 time frame. The theoretical-methodological discussion is supported by Ausubel (2003), Moreira (2012), Therrien (2010), among others. The results show that there is very little production of papers addressing the Research Knowledge and Meaningful Learning categories in the discussion of the Mathematics teacher's knowledge, which leads us to consider that this is a category that has not yet been consolidated. It is increasingly necessary to research, discuss and reflect on their training needs.

Keywords: Continuing education. Mathematics Teacher. Meaningful learning. Research knowledge. State of the matter. 


\section{RESUMO}

O artigo traz discussões sobre os Saberes da pesquisa na formação continuada de professores(as) de Matemática para Aprendizagens Significativas. É uma revisão de literatura que levantou a seguinte indagação para a construção do Estado da Questão: o que já existe produzido academicamente sobre as contribuições da prática da pesquisa para o desenvolvimento de aprendizagens significativas, considerando a prática pedagógica do(a) professor(a) de Matemática do 60 ano, em sua formação continuada? Objetivou mapear o que existe de produção científica sobre os Saberes da pesquisa na formação continuada de professores de Matemática para Aprendizagens Significativas. Para as buscas nas bases de dados aplicamos o recorte temporal 20002021. A discussão teórico-metodológica se sustenta em Ausubel (2003), Moreira (2012), Therrien (2010), dentre outros. Os resultados apontam que existe pouquíssima produção de trabalhos abordando as categorias Saberes da Pesquisa e Aprendizagem Significativa na discussão sobre os saberes do(a) professor(a) de Matemática, o que nos leva a considerar tratar-se de uma categoria ainda não consolidada. É necessário pesquisar, discutir e refletir sobre suas necessidades formativas.

Palavras-chave: Aprendizagens significativas. Estado da questão. Formação continuada. Professor(a) de matemática. Saberes da pesquisa.

\section{RESUMEN}

El artículo trae discusiones sobre el conocimiento de investigación en la educación continua de los profesores de Matemáticas para el Aprendizaje Significativo. Se trata de una revisión de la literatura que planteó la siguiente pregunta para la construcción del Estado de la Cuestión: ¿Qué ya se ha producido académicamente, sobre las contribuciones de la práctica investigadora al desarrollo de aprendizajes significativos, considerando la práctica pedagógica del docente de 6 grado Matemáticas en su educación continua? El objetivo fue mapear lo que existe de producción científica acerca del conocimiento de investigación en la formación continua de profesores de Matemáticas para el aprendizaje significativo. Para las búsquedas en las bases de datos, se aplicó el período de tiempo 2000-2021. La discusión teórico-metodológica es apoyada por Ausubel (2003), Moreira (2012), Therrien (2010), entre otros. Los resultados apuntan que hay poquísima producción de trabajos que abordan las categorías de conocimiento de investigación y aprendizaje significativo en la discusión del conocimiento del docente de Matemáticas, lo que nos lleva a considerar que esta es una categoría que aún no se ha consolidado. Es necesario investigar, debatir y reflexionar sobre sus necesidades formativas.

Palabras clave: Aprendizaje significativo. Conocimiento de investigación. Estado de la cuestión. Formación continua. Profesor de matemáticas.

\section{INTRODUCTION}

The insertion in the practice of research is an invitation to autonomy, to walk along paths, as Fernando Pessoa says, which demand boldness, because "if we do not dare to do it, we will have been forever on the sidelines of ourselves", which it also implies "forgetting our paths that always lead us to the same places". It refers to a dialectical process of construction of individual subjectivity, dependent on interpersonal relationships developed in the lived space, whose constructive process needs to be centered "on experiences that stimulate decision and responsibility, that is, on experiences respectful of freedom" (Freire, 2011, p. 121).

From the research point of view, these "respectful experiences of freedom" reveal the perspective of the researcher breaking with "the orthodoxy of fidelity to a single epistemological/methodological paradigm", while "taking several disciplinary fields to build their knowledge" (Barbosa, 1998, p. 30). 
Here is freedom? However, according to Barbosa (1998, p. 32), this "cannot justify dispersion, lack of rigor or scientific superficiality". Corroborating this direction, Kincheloe points out that the researcher who accepts the invitation to "abandon the clothes that already have the shape of his body", [...] he abandons the search for some naive concept of realism, concentrating instead, in the elucidation of their position in the web of reality and in the social places of other researchers and in the ways in which they shape the production and interpretation of knowledge (Kincheloe, 2007, p. 16).

Therefore, we understand the relevance of the knowledge and realization of the State of the Question, a typology of scientific research with a quantitative and qualitative approach, of a bibliographic nature, which contributes to a movement of coming and going, which involves discipline and organization, sensitivity, creativity and planning for direct the search, providing reference to what exists in publications in our research area, in our profession, whether locally, nationally or internationally. In this way, mapping what exists in science about our subject of study: Research knowledge in the continuing education of Mathematics teachers for Meaningful Learning (Nóbrega-Therrien \& Therrien, 2010).

Research knowledge, such as those that mainly involve teachers and students in a potential action on the teaching and learning processes, from the work with knowledge, in a relationship of approximation between theory and practice, based on experiences with the stages of a scientific investigation, considering all its phases as a didactic-methodological strategy.

This research knowledge refers to those that do not decompose components in a way that separates, in an extreme case, the scientific disciplinary knowledge (Mathematics) and, in the other case, the pedagogical, curricular and experiential knowledge, among others. Rather, they enable teachers to be able to regulate or guide pedagogical practice and to describe or explain the richness and complexity of educational phenomena, thereby broadening their perceptions of the learning process, thus avoiding the separation between the world of investigation and the universe of classroom practice, which seems to us to form independent circles, surrounding themselves, without meeting. In this direction, when weaving reflections on teacher education, Pimenta (2002) understands that

[...] recent approaches to the epistemology of practice - understanding teaching as a complex phenomenon, the school space as a whole and valuing research, in collaboration between university researchers and teachers in schools, in the movement of critical and collective reflection of practices - they would be pointing out for the possible overcoming of an individualistic perspective in favor of a public perspective of social commitment, of school practices (Pimenta, 2002, p. 50).

In this understanding, venturing on this arduous but pleasant journey, this uncovers the meaning of the word research that crosses, semantically and essentially, by the idea of diligently searching, investigating, finding out about, inquiring - attributions that the human being took it upon itself, or were attributed to it since its genesis. In other words, as if the individual's natural curiosity and research were inseparable elements.

Right now, the fundamental principle of Ausubel's Theory of Meaningful Learning highlights that prior knowledge is the isolated variable that most influences the significant acquisition of new knowledge, therefore, it cannot be ignored. It aims to make it clear that his theory cannot be taken for granted. We highlight the year 2000, within the scope of the questions about what and how students can learn meaningfully, in which there was an effervescent and, not little, confused publication of articles using Ausubel's theory as a theoretical reference, without the philosophical appropriation underlying it.

According to Moreira, there was a superficial and polysemic appropriation of the concept of Meaningful Learning, and "[...] all learning became significant, all teaching methodologies began to 
aim at meaningful learning. A trivialization of the concept" (Moreira, 2012, p. 25). Thus, the year 2000 portrayed Ausubel's thought reiterated in his most current book, explaining that his Theory is more concerned with the significant acquisition of an organized body of knowledge in a formal teaching and learning situation.

In this perspective, aiming to "abandon the used clothes" and live the/time of the crossing, in the study we developed, we initially asked for the construction of the State of the Question: what has already been produced academically about the contributions of research practice to the development of significant learning, considering the pedagogical practice of the 6th grade Mathematics teacher in their continuing education?

The following theoretical-methodological discussion is supported by Ausubel (2003), Moreira (2012), Therrien (2010), among other authors referenced according to our clipping, as well as presenting critical-reflective elements, regarding the results and conclusions of the scientific works found. The opportunity also broadens discussions on perceived gaps, thus being able to point out possibilities for further studies, as well as new research being raised. Based on this understanding, we consolidated the time frame to establish the searches and reading of the material found in the databases, which covered the period from 2000 to 2021.

\section{On the tracks of the object of study}

In the first readings, we noticed the changes that began to occur in the Brazilian research scenario, in the early 1990s, resulting both from the influence of international literature that arrives in the country and, for example, the works of Tardif et al. (2000), Gauthier et al. (1998), as well as studies by Brazilian researchers, such as Fiorentini (2005), Nacarato (2005; 2009; 2013), D'Ambrósio (1998; 2000; 2002), Borba (2010), Pimenta (2005; 2006; 2010; 2011), Therrien (2006; 2010), among many others.

Important agendas were highlighted, which enabled the growing increase in Brazilian research, and the heating of discussions with the enactment of the Law of Guidelines and Bases (LDB) No. 9394/1996, enabling studies and reflections on the initial and continuing education of teachers, the knowledge needed in this training process, about the prevailing conceptions in relation to the teaching-learning process, as well as the multiplicity of constructs about Meaningful Learning. Through these themes, realize what looks were directed to Elementary School, specifically, to the 6th grade, a period marked by the break between Elementary I (early years), which is assisted by the professional pedagogue, to Elementary School II (final years), which is taught by the Mathematics teacher, represents a necessary highlight for this study, as the students are in this transitional phase.

In this direction, Melin (2013) points out in his dissertation entitled The transition to Elementary School II: motivation for mathematics in relation to the perceived social context, that researchers have highlighted the issue of student motivation at this stage and the relevance of social classroom environment, as important academic outcomes such as performance and persistence are often directly related to these factors. In this context, Barreto et al. (2013, p. 73) emphasize for a fundamental analysis of the essence of Mathematics, which should be perceived as an instrument for knowledge of the world and mastery of nature, which is an "answer in search of survival and transcendence", and "without it, the human being would not have been able to leave the caves, for some time later to invent the computer, and travel through outer spaces."

This reinforces what research continues to announce about teacher education, whether initial or continuing, that more attention is needed to this training process, in which "the mastery of mathematical and pedagogical knowledge makes the Mathematics teacher more flexible in the classroom, able to choose the most appropriate tasks for the development of the most significant and motivating mathematical discussions" (PONTES, 2009, FIORENTINI, 2003; CURY et al., 2002; BARRETO, CARVALHO, VIANA, 2013) 
Developed researches around this theme (IBIAPINA, 2008; RAMALHO, NÚNEZ, GAUTHIER, 2005; GUEDES, 2006; THERRIEN, 2002; 2006; 2008; FIORENTINI, 2002; 2005) they argue that, despite the systemic training experienced by teachers, it has not fully enabled the apprehension and articulation necessary to understand the teaching work, given that the knowledge that the teacher uses in their work is more than a set of theoretical propositions. In this context, D'Ambrósio's reflections (2009, p. 80) highlight that, "[...] the great challenge for education is to put into practice today what will serve for tomorrow". And,

[...] putting into practice means taking theoretical assumptions, that is, a knowledge/doing accumulated over past times, to the present. The effects of today's practice will manifest in the future. If this practice was correct or wrong, it will only be noticed after the process and this will serve as a subsidy for a reflection on the theoretical assumptions that will help to review, reformulate, improve the know-how that guides our practice. (D'Ambrósio, 2009, p. 80)

Thus, the exercise of the teaching activity is configured as a space for reflection on practices, based on theoretical elements that enable the construction of knowledge, according to experiences and critical analyzes of reality in the classroom. However, when it comes to the practice of the Mathematics teacher, the representation that teaching mathematics is to work with numbers, measures, geometric shapes is still very strong and present, and it presupposes above all to provide opportunities for the student to take a stand, take decisions, argue, Dialogue and communicate ideas, because learning Mathematics is learning how to solve problems.

Therefore, it is challenging and necessary to create spaces for continuing education in which teachers can reflect and discuss with their peers the meaning of mathematical activity, problematizing their practices and sharing the new meanings that will emerge for the issues that will be worked on in the daily practice, which in turn allows us to highlight the importance of research knowledge as the link between theory and practice.

Therefore, the search for productions about the Mathematics teacher and research knowledge reinforces the understanding and the need to remember that, "[...] in methodological terms, research is a procedure surrounded by more or less formal and logical rigors, being inappropriate to apply the concept to anything". Therefore, this comprehension drives to admit research as an educational and training principle that aims to contribute in a critical-reflective way to "create" a scientific culture for the construction of autonomous knowledge, harboring the intention to motivate significant advances in terms of quality in the processes of learning, which implies, a priori, rethinking and redoing teacher training (Demo, 2008, p. 105).

\section{METHODOLOGY}

This journey was determined by the chosen databases, namely: (1) CAPES Theses and Dissertations Database; (2) Digital Library of Theses and Dissertations - BDTD; (3) Bolema Magazine of the Brazilian Society of Mathematics Education, whose first edition dates back to 1985; (4) Meaningful Learning in Magazine comprising 18 issues from 2011 to 2017; (5) CAPES journal portal; (6) The events of the National Association of Post-Graduation Studies and Research in Education ANPED, Working Group (GT) - 19 Mathematics Education; and (7) North and Northeast Educational Research Meeting - EPENN, in GT - 19 Mathematics Education.

The searches were started in March 2018 in these sites, as a result of the subject State of the Question, offered by the Graduate Program in Education of the State University of Ceará - UECE, in which the data were continuously updated until February 2021. Initially, a broader query was 
carried out using the knowledge of the Mathematics teacher in quotation marks, then we applied the Boolean ${ }^{1}$ AND in the combined terms presented in table 1.

Table 1. Combined terms.

\begin{tabular}{|c|c|c|c|}
\hline $\begin{array}{l}\text { "Knowledge of the } \\
\text { Mathematics Teacher" }\end{array}$ & $\begin{array}{c}\text { Knowledge AND } \\
\text { Mathematics Teacher }\end{array}$ & $\begin{array}{l}\text { Knowledge of research } \\
\text { AND professor of } \\
\text { Mathematics }\end{array}$ & $\begin{array}{l}\text { Research knowledge AND } \\
\text { pedagogical practice of } \\
\text { the Mathematics teacher }\end{array}$ \\
\hline $\begin{array}{l}\text { Knowledge of the } \\
\text { research AND } \\
\text { pedagogical practice of } \\
\text { the Mathematics } \\
\text { teacher in the 6th grade }\end{array}$ & $\begin{array}{c}\text { Knowledge of the } \\
\text { research AND } \\
\text { pedagogical practice of } \\
\text { the Mathematics } \\
\text { teacher in the 5th } \\
\text { grade }^{2}\end{array}$ & $\begin{array}{l}\text { Knowledge of the } \\
\text { research AND } \\
\text { Significant Learning }\end{array}$ & $\begin{array}{l}\text { Research knowledge AND } \\
\text { significant learning in } \\
\text { Mathematics }\end{array}$ \\
\hline $\begin{array}{l}\text { Knowledge of the } \\
\text { research AND Significant } \\
\text { Learning in the 6th } \\
\text { grade }\end{array}$ & $\begin{array}{l}\text { Research knowledge } \\
\text { AND significant learning } \\
\text { in 5th grade }\end{array}$ & $\begin{array}{l}\text { Knowledge of research } \\
\text { in mathematics } \\
\text { teaching AND 6th } \\
\text { grade }\end{array}$ & $\begin{array}{l}\text { Knowledge of research in } \\
\text { mathematics teaching } \\
\text { AND 5th grade }\end{array}$ \\
\hline
\end{tabular}

In refining the data, we used filters: (a) time frame 2000 to 2021; (b) area of knowledge in Education and Mathematics Education; (c) Capes journals portal, peer-reviewed articles; (d) at the ANPEd and EPENN events, we selected articles and posters. After establishing the filters, titles and abstracts were read. From this selection, texts that did not refer to the object of study were excluded, and those selected were read in full.

\section{RESULTS}

In table 2 we present the path and the quantitative results acquired in the process.

Table 2. Route and general result.

\begin{tabular}{cccc}
\hline Repositories & Selected & Selected post abstract & Selected post text \\
\hline Thesis/dissertations CAPES and BDTD & 310 & 07 & 07 \\
CAPES journals & 150 & 03 & 03 \\
Bulletin and in magazine & 186 & 01 & 01 \\
ANPED and EPEN & 01 & 01 & 00 \\
\hline Total & 647 & 11 & 11 \\
\hline
\end{tabular}

Thus, of the 288 dissertations, 22 theses, 150 articles from capes periodicals, 186 articles from the two consulted magazines (Bolema and Significant Learning in Magazine) and 01 work from 22 meetings/events, totaling 647 works, there were 11 left to be read fully, considering that, previously, we used as exclusion criteria, after using Booleans and combined, three relevant aspects: (1) not presenting a relationship with the object of study in the title of the work; (2) not showing any approximation with the object of study in the abstract; and (3) If it pointed out any relationship, in the title, in the abstract, and did not relate to the focus of the study. In sequence, after clarifying the exclusion criteria, I sought, by reading the 11 works, to consolidate those that were related to

\footnotetext{
${ }^{1}$ The name of mathematician George Boole is at the origin of Boolean logic, which is based on set theory. The Boolean operators AND, OR, NOT serve to combine several terms in the same search, which serve to define the search system, how the combination between the terms or expressions of a search, whose intention is the same - restrict or broaden Search for more accurate results. Available in: http://www.dbd.puc-rio.br/wordpress/?p=116

${ }^{2}$ Considering the change in the nomenclature, as a result of Law No. 11,274, of February $6^{\text {th }}, 2006$, which extends Elementary Education to nine years of duration.
} 
the theme/object of research, and among these, those that would be read and analyzed for the construction of our theoretical framework.

As a result of these choices, the general composition was outlined and presenting the findings, which after filters and refinements are presented in table 3.

Table 3. Selected works for analysis.

\begin{tabular}{|c|c|c|c|c|}
\hline Author (s) & Bases & Type & Title & Space \\
\hline $\begin{array}{l}\text { Silva, } \\
\text { Rosimeyre } \\
\text { Vieira da } \\
(2015)\end{array}$ & $\begin{array}{l}\text { Capes and BDTD } \\
\text { theses/dissertations }\end{array}$ & Master's degree & $\begin{array}{l}\text { Articulation of teaching and research } \\
\text { in teaching practice: experiences and } \\
\text { meanings of teachers in the teaching } \\
\text { courses of the Federal Institute of } \\
\text { Education of Piaui }\end{array}$ & PPGE-UFPI \\
\hline $\begin{array}{l}\text { Bertini } \\
\text { Luciane de } \\
\text { Fátima (2009) }\end{array}$ & $\begin{array}{l}\text { Capes and BDTD } \\
\text { theses/dissertations }\end{array}$ & Master's degree & $\begin{array}{l}\text { Sharing knowledge in teaching of } \\
\text { mathematics in the early grades: a } \\
\text { teacher in the context of } \\
\text { investigative tasks }\end{array}$ & $\begin{array}{l}\text { Federal University } \\
\text { of São Carlos }\end{array}$ \\
\hline $\begin{array}{l}\text { Alves, José } \\
\text { Flaudemir } \\
\text { (2004) }\end{array}$ & $\begin{array}{l}\text { Capes and BDTD } \\
\text { theses/dissertations }\end{array}$ & Master's degree & $\begin{array}{l}\text { Teacher education and school } \\
\text { practice: dilemmas and perspectives } \\
\text { for teaching Mathematics with } \\
\text { research }\end{array}$ & $\begin{array}{l}\text { Pontifical Catholic } \\
\text { University of } \\
\text { Campinas }\end{array}$ \\
\hline $\begin{array}{l}\text { Camelo, Zélia } \\
\text { Beserra (2020) }\end{array}$ & $\begin{array}{l}\text { Capes and BDTD } \\
\text { theses/dissertations }\end{array}$ & Master's degree & $\begin{array}{l}\text { Pedagogical technological knowledge } \\
\text { and content in the training of spatial } \\
\text { geometry teacher }\end{array}$ & $\begin{array}{l}\text { Post-graduate in } \\
\text { Education -UECE }\end{array}$ \\
\hline $\begin{array}{l}\text { Sousa, } \\
\text { Cleângela } \\
\text { Oliveira (2018) } \\
\end{array}$ & $\begin{array}{l}\text { Capes and BDTD } \\
\text { theses/dissertations }\end{array}$ & Master's degree & $\begin{array}{l}\text { Continuing teacher education and } \\
\text { the concept of space: contributions } \\
\text { from the Meaningful Learning theory }\end{array}$ & $\begin{array}{l}\text { Post-graduate in } \\
\text { Education -UECE }\end{array}$ \\
\hline $\begin{array}{l}\text { Neto, Orestes } \\
\text { Zivieri (2009) }\end{array}$ & $\begin{array}{l}\text { Capes and BDTD } \\
\text { theses/dissertations }\end{array}$ & $\begin{array}{l}\text { Doctorate } \\
\text { degree }\end{array}$ & $\begin{array}{l}\text { Time and knowledge: the } \\
\text { constitution of the experienced } \\
\text { teacher in Mathematics }\end{array}$ & $\begin{array}{l}\text { UNESP - São } \\
\text { Paulo State } \\
\text { University, } \\
\text { Faculty of } \\
\text { Sciences and } \\
\text { Literature of } \\
\text { Araraquara and } \\
\text { Federal University } \\
\text { of Rondônia }\end{array}$ \\
\hline $\begin{array}{l}\text { Silvano, } \\
\text { Antonio } \\
\text { Marcos (2019) }\end{array}$ & $\begin{array}{l}\text { Capes and BDTD } \\
\text { theses/dissertations }\end{array}$ & $\begin{array}{l}\text { Doctorate } \\
\text { degree }\end{array}$ & $\begin{array}{l}\text { Teacher knowledge and meaningful } \\
\text { learning in initial teacher education } \\
\text { using interactive digital interfaces }\end{array}$ & $\begin{array}{l}\text { Post-graduate in } \\
\text { Education -UECE }\end{array}$ \\
\hline $\begin{array}{l}\text { Farina, } \\
\text { Cynthia; } \\
\text { Albernaz, } \\
\text { Roselaine } \\
\text { Machado } \\
(2010) \text {, }\end{array}$ & Capes Journals & Article & $\begin{array}{l}\text { Mathematics Teacher: knowledge in } \\
\text { moving training }\end{array}$ & $\begin{array}{l}\text { INTERthesis } \\
\text { Magazine }\end{array}$ \\
\hline $\begin{array}{l}\text { VALENTE, } \\
\text { Wagner } \\
\text { Rodrigues } \\
(2008)\end{array}$ & Capes Journals & Article & Who are we Mathematics teachers? & Cedes Journal \\
\hline $\begin{array}{l}\text { Wichnoski, } \\
\text { Paulo (2017) }\end{array}$ & Capes Journals & Article & $\begin{array}{l}\text { Metasearch in mathematical } \\
\text { research: an analysis from the } \\
\text { abstracts }\end{array}$ & $\begin{array}{l}\text { Mathematics } \\
\text { Education } \\
\text { Research } \\
\text { Magazine } \\
\end{array}$ \\
\hline $\begin{array}{l}\text { Ben-Chaim, } \\
\text { David; Bat- } \\
\text { Shevallany } \\
\text { YaffaKeret } \\
\text { (2008) }\end{array}$ & Bolema Magazine & Article & $\begin{array}{l}\text { Authentic Investigative Activities for } \\
\text { the Teaching of Ratio and Proportion } \\
\text { in the Training of Mathematics } \\
\text { Teachers for Elementary and High } \\
\text { School Levels }\end{array}$ & Bolema Magazine \\
\hline
\end{tabular}




\section{DISCUSSION}

In Rosimeyre Vieira da Silva's master's research, defended in 2015 at UFPI, on the Articulation of teaching and research in teaching practice: experiences and meanings of teachers in undergraduate courses at the Federal Institute of Education of Piaui, an analysis is evidenced that assumes that teaching has in research an indispensable element for its complement, improvement and that teaching to/with research is a formative requirement of the contemporary context.

The results of this investigative process point out that the professional history and experience of teachers were essential for understanding the meanings they attributed to the articulation between teaching and research. Thus, among the elements necessary for the implementation of actions aimed at articulating teaching and research, there is the greatest incentive to research by the IES - Higher Education Institution and the training needs on research knowledge by the professors.

I note that this dissertation brings conclusive highlights that approach the questions I propose to raise, and it helps to reflect on the "training needs on research knowledge" as a necessary shift for a repositioning of educational institutions in relation to curricular issues and propositions and formative of contemporaneity, no longer in a unidirectional perspective, without paying attention to what the teacher needs to learn, but allowing them to position themselves, elaborate, re-elaborate and produce knowledge in light of their discoveries, training demands, studies and perceptions.

In the dissertation defended by Luciane de Fátima Bertini in 2009 at UFSCar: Sharing knowledge in the teaching of Mathematics in the early grades: a teacher in the context of investigative tasks, it was possible to perceive the option for such tasks as the focus of the research, reflecting the search to overcome the Mathematics teaching based on the reproduction of procedures and algorithms.

The research was carried out with students from the 3rd grade corresponding to the current 4th grade, in defense of investigative tasks because they propose a change in the classroom dynamics, involving students more actively in their learning, and mainly encouraging creativity and reflection. The question that guided the development of the research was: What are the potentials and limitations of the use of investigative tasks in the teaching of mathematics in the early grades of elementary school, based on the actions and reflections of a teacher?

According to Bertini (2009), some potentialities of carrying out investigative tasks in Mathematics teaching are noticeable, such as: encouraging autonomy and creativity; development of the ability to argue and register; pursuit of differentiated strategies, mobilizing mathematical knowledge. Limitations were also identified, namely: the time to develop the task; the break between classes; children's inexperience with argumentation and recording; the unpredictability generated by the opening in the proposal.

We realize that it is important to pay attention to the identification of potentials, possibilities, but also the limitations that are presented to develop research practices as an articulating principle of the teaching and learning process, given that it is an action that provokes problematizing thinking, propositional and stimulator of comprehensive, critical and interventional skills, which presupposes demanding adequate planning of time considering all the possible unpredictability generated by the opening of the proposal in Mathematics classes.

José Flaudemir Alves, in his dissertation defended in 2004 at PUC-Campinas entitled Teacher training and school practice: dilemmas and perspectives for teaching Mathematics with research, he aimed to seek reflections on how teaching with research is present in the formation of the Mathematics teacher and in their practice. Data on the conception of these teachers regarding research and its use in the development of work in the classroom were analyzed.

However, the data obtained in the research by Alves (2004) revealed a lack of information and security on the subject, showing an urgent need for reflection on how initial and continuing 
teacher education courses for research work are being developed. These conclusions reinforce the relevance and timeliness of our object of study. The field research was carried out with Mathematics teachers, principals and school coordinators who work in Elementary and High School, both in the public network of the State of São Paulo and in the municipal network, all working in the city of Paulínia - SP.

In this research, it was possible to verify approximations with our object of investigation, considering the methodological path adopted in this work, which sought to apprehend the research knowledge in the context of the continuing education of Mathematics teachers, seeking to identify elements that signal the training needs of teachers in relation to their pedagogical practice with research.

I believe that establishing the development of an investigative posture as a basic element in the context of teacher training courses represents broadening and favoring the creation of an environment for negotiation of meanings and communication of ideas that bring "[...] the reconstructive questioning, which encompasses theory and practice, formal and political quality, innovation and ethics", which is "the differential research criterion" (Demo, 2002, p. 01).

In the dissertation Pedagogical technological knowledge and content in the training of the spatial geometry teacher, by Zélia Beserra Camelo, defended in 2020 at UECE, she highlights in her investigation, characterized as action research of a qualitative nature, analyzes on the evidence of content knowledge, pedagogical content knowledge, pedagogical technological knowledge and content in the practice of high school Mathematics teachers, from the formative process directed to the teaching of Spatial Geometry.

The work of Professor Zélia Camelo brings important considerations about continuing education for Mathematics teachers, which soon became evident that this is a formative stage little experienced by teachers in the area, and that technological resources are an important tool to assist and implement teaching and learning. She believes that the reflections outlined in this formative stage have contributed to "rethinking" the practices of the participating teachers, as a possibility of expanding the knowledge domain of the Mathematics teachers. So, her reflections contribute to ours as well.

The dissertation Continuing teacher education and the concept of space: contributions of the Meaningful Learning theory, defended in 2018 at UECE by Cleângela Oliveira Sousa, it aimed to analyze the contributions of the Meaningful Learning Theory (TAS) in the continuing education of pedagogue teachers who they teach Mathematics in the 1st grade of Elementary School. The researcher worked with the hypothesis that the Ausubelian theory favors teaching work with concepts related to space in geometry, with elements for a more meaningful learning.

Her Action Research helped us to think and realize that the crossing we wanted to make along the paths of the TAS was relevant, considering that the results showed signs of changes in the planning of classes and in the practice of teachers, based on discussions and new knowledge built during the training activities, highlighting the desire and need to continue studies on the topics covered. It showed that the Action-Research promoted voluntary involvement, collaboration and respect among teachers, as well as the potential for work and collective reflection. It was highlighted that the work contributed to the Mathematics training of teachers who teach in the early years and enrich the debate about the contributions that TAS can bring to the teaching of space in Mathematics.

In this way, we continued our journeys through the bases and we identified in the doctoral thesis defended by Orestes Zivieri Neto in 2009 at UNESP: Time and knowledge: the constitution of an experienced teacher in Mathematics who aimed to raise the basic knowledge and action of teachers (Ponte, 1997), or of subject or class management (GAUTHIER et al., 1998) in Mathematics, to verify, in their trajectory, whether time determines mutations in their daily activities, and in the level of awareness that these professionals have of their theoretical-practical articulation. The study 
was also focused on characterizing the experienced teacher who emerges from the practice of knowledge amalgamated in daily experience, from their phases of the teaching career.

It highlights the invisibility of knowledge from experience and shows the knowledge and conceptions of experienced Mathematics teachers. It reveals the role that time plays in the versatility of experiences, assuming, along with career time, what the school tradition will attribute to teachers considered to be more experienced, the fact that they have and make use of their knowledge that, accumulated, will offer them sharper insights and more diverse dynamics. However, in that work, the research knowledge in the performance and training of Mathematics teachers are not mentioned.

It is appropiate to consider the reflections caused by this production that emphasizes the experiential knowledge of the Mathematics teacher, giving due importance to knowledge at/of school, conceiving it as "suitable for learning", a locus that integrates training elements, and that, above all, they can be an instrument for educational management and for the development of pedagogical proposals for training, thinking about this set, about the training of trainers, for example.

The thesis Teaching knowledge and meaningful learning in initial teacher education with the use of interactive digital interfaces, by Antonio Marcos Silvano, defended in 2019 at UECE, it aimed to analyze the implications of the principles of the Theory of Meaningful Learning in the process of initial education of teachers for the construction of teaching knowledge necessary for the pedagogical use of Interactive Digital Interfaces (IDI), in the perspective of interdisciplinarity in the study of trigonometric functions applied to sound phenomena.

The work brings a qualitative approach based on the assumptions of the Action Research method, in the context of degrees in Mathematics and Physics, pointing out as results that the teaching knowledge (knowledge, pedagogical, digital, experience, among others) still needs to be resumed and/or matured with the undergraduates and that the teaching courses, by themselves, do not meet these needs to supply all the skills and abilities that are inherent to the process of training future teachers of Basic Education.

Thus, it emphasizes that the construction of competencies and skills for the appropriation, insertion and use of IDI in pedagogical practice is a complex process that requires training and time to consolidate professional experiences and development of knowledge and knowledge to articulate pedagogical potentialities and cognitive effects of these resources. I consider this production is relevant to the discussions that are necessary, at this time of pandemic, in contexts of remote classes, especially later.

The article entitled Mathematics Teacher: knowledge in moving formation, by Cynthia Farina and Roselaine Machado Albernaz (2010), deals with the formation of the Mathematics teacher based on their experiences in the school environment and the knowledge that constituted them. historically, philosophically and politically. According to the authors, this knowledge is not limited to academic knowledge, but it involves the subjective effects of the scientific knowledge that it incorporates.

In order to problematize the formation and knowledge of the character/participant, their ways of being, thinking and perceiving, they question, with and through it, the new requests made to Mathematics teachers and the knowledge that constitutes them as such, his way of acting and positioning himself in the school universe. The proposed essay sought an articulation between the fields of Art, Philosophy, Science and Education, showing with emphasis on the knowledge of a teacher's experience, that the ways in which she has been formed and has been formed have occurred from a "set of such logical knowledge, as subjective and sensitive" (Farina \& Albernaz, 2010, p. 320).

Taking into account this fabric of knowledge that constitutes and forms a teacher, Therrien $(2010$, p. 8) points out the pedagogical rationality that articulates this understanding of access to 
knowledge, referring to "the way each subject, group, or community articulates its knowledge and knowledge to understand a phenomenon, the world, life or to justify its way of acting, its objectives and means to achieve them". In this way, valuing and mobilizing the knowledge of reflection, theories, research, didactic-pedagogical knowledge and confronting them with their experiences, in a critical-reflective-communicative stance on the actions we carry out, enable the resignification of teaching practices.

We conceive that the valuation of the integration of research knowledge in the training and practice of Mathematics teacher oriented and based on its emancipatory character, considering it as a constitutive element of learning, as well as of its professionality, it attributes a situated understanding about being a teacher and the multiple determinants related to your pedagogical practice.

The study by Valente Rodrigues (2008) entitled Who are we, mathematics teachers? He highlights the importance of considering the work of the Mathematics teacher in a historical dimension that allows for a different understanding of the meaning of the actions carried out in classrooms today. He argues that reaching science from contexts of other times in mathematics teaching enables the understanding of what are novelties and continuities in the daily task of teaching mathematics to children, young people and adults.

The author concludes that the profession of being a Mathematics teacher, like most professions, is heir to practices and knowledge that come from different times. The understanding of their knowledge goes through to understand the reason for being: Why do we teach? What do we teach our students? and How do we teach? Why do we value certain practices and not others? Who are we Mathematics teachers? These are basic questions that a historical analysis can help to answer.

Advancing in the searches and reflections they provoked, it was possible to find the work Metaresearch in mathematical research: an analysis based on the abstracts of the XIV CIAEM, by Paulo Wichnoski (2017), which aimed to understand and explain the research in IM - Mathematical Research in the context of Mathematics Education, based on abstracts of works published at the XIV CIAEM (Inter-American Conference on Mathematics Education). It was raised as a research problem: what is shown about research in Mathematical Research in the context of Mathematics Education in the abstracts published in the XIV CIAEM?

The findings reveal that the area in question is in incipient development as a field of research, opening up ample possibilities for investigations. One of them, which was not questioned by the researches published in the scope of the event, concerns the initial formation of Mathematics teachers with a view to Mathematical Research.

In Bolema magazine ${ }^{3}$, specifically in the article Authentic Investigative Activities for Teaching Ratio and Proportion in Mathematics Teacher Training for Elementary and High School levels (2008), the authors David Ben-Chaim, Bat-Shevallany and YaffaKeret present elements related to creation, implementation and evaluation of the impact of the so-called "authentic investigative activities" that focus both content and pedagogical knowledge and attitudes in the initial training of Mathematics teachers for elementary and high school levels. These activities were developed in Israeli institutions dedicated to teacher training.

The application of the model - through which teachers gain experience and are exposed to "authentic" proportional reasoning activities, incorporating theory (by reading and analyzing relevant research texts) and practice, produced a significant change in the approach to content mathematics and pedagogical knowledge.

\footnotetext{
${ }^{3}$ It is one of the oldest and most important publications in the field of Mathematics Education in Brazil. Created in 1985, Bolema was born from the initiative of a group of post-graduate students from the Post-Graduate Program in Mathematics Education at UNESP in Rio Claro - the first post-graduate study center in this area in Latin America.
} 
These authentic investigative activities enabled teachers to produce significant learning from the Mathematics activities from/with research learning in the 6th grade. Therefore, it was presented as a strategy for continuing education as a fundamental and complementary activity to the initial training of teachers, as it can be an articulator of scientific knowledge of mathematics with the didactic aspect, and it can promote the deepening of specific knowledge and reflection on the practice.

Reading this article allowed us to meditate on our reality in Brazilian institutions, specifically in the training of Mathematics teachers, because to think about the professional constitution of these teachers considering only the "[...] period of initial training, regardless of continued training, namely, from what happens in the work process itself, is to deny the life story of the future teacher; is to deny him as a subject of possibilities" (Fiorentini \& Castro, 2003, p. 124).

In this context, they deny their knowledge that is plural, complex, reflexive, based on a historical, cultural, affective and contextually significantly provisional construct, considering the dynamism that marks their teaching, because, above all, these moments and continuous training spaces they can contribute to minimize the distance between the ideals and the everyday realities of the classroom, combat the fragmentation of work, of the content itself, enhancing the contextualization and integration of the pedagogical relationship with the construction of mathematical knowledge in Basic Education.

Observing these results, it is worth emphasizing that research can favor both in initial and continuing education a process of understanding, investigation and construction of understandings for the pedagogical activity of the Mathematics teacher, given that it is a phenomenon in permanent movement, not linear, nor completely measurable. It is in this context that we come closer, bringing with the object of investigation the possibility of continuing education for Mathematics teachers through the practice of investigation/research.

\section{CONCLUSION}

Reading the papers allowed us to conclude that there is very little production of papers addressing the category Knowledge of Research and Meaningful Learning in the discussion about the knowledge of the Mathematics teacher, which leads us to consider that it is a category that has not yet been consolidated. Although other categories appear, such as: teaching by investigation, scientific knowledge, investigative activities, research in mathematical investigation, they do not include our object of study.

However, the productions that deal with teaching and meaningful learning are expressive, in the scope of Chemistry, Physics, Biology, Informatics, Electrical Engineering, Arts, Philosophy and Physical Education. It is noticed that there is a centralization of studies in the area of Mathematics, specifically in High School, and, above all, in Chemistry.

Considering the works analyzed, regarding the theoretical-methodological option, it is observed that, since 2000, researches with a qualitative, participatory and collaborative approach have been highlighted, with predominance of investigations of the Action Research, Case Study of Ethnographic Type and Narrative Research, with hybrid methodological paths. In this way, they sustain that researcher and researched are interacting in the research field, with the collaborator actively participating in the process, having the possibility not only of providing data to the researcher, but also of assuming the author of the story.

Based on this assumption, the researcher teacher has the opportunity to insert himself in a critical, creative, creative, exercise of freedom, dialogic process, and, it seems to us that it is also handy and multi-referential ${ }^{4}$, so why not see and read the complexity of the real world with other

\footnotetext{
${ }^{4}$ See: BARBOSA, Joaquim (org). Reflections on the multi-referential approach. São Carlos: UFSCAR, 1998. KINCHELOE, Joe L.; BERRY, Kathleen S. Education research: conceptualizing bricolage. Porto Alegre: ArtMed, 2007.
} 
lenses? In this sense, the complex world demands multi-referential, plural and proportionately complex questions, which will enable various forms and methods to provide richness and depth that reveal meanings to studies and research. This finding rests on the need to seek an effort to address the complexity of everyday life considering the search for different epistemologies.

Based on these foundations, it is clear that it becomes possible to ask new questions related to epistemology and the act of research, demanded for complex social, cultural and educational analysis. We also believe that questions move the world, and can lead to significant learning, discovering and experiencing different methodologies, based on complex, multidimensional, interdisciplinary work. Exercising, as handymen do, at many levels of understanding and knowledge: they are dedicated to questioning and learning from what was excluded by the "tyranny of reductionism".

Thus, it is essential to guide our reflections on the pedagogical practice of the Mathematics teacher, without disregarding three aspects that lead us to their knowledge: 1) having a clear perception that it is not enough to just master the mathematical content; 2) deconstructing the thought that it is unnecessary to seek other specific knowledge, because to teach, the transmission of knowledge is enough; 3 ) valuing the knowledge produced by the academy, without considering the concrete conditions of the exercise of teaching, including those related to concrete experiences in relation to the theory-practice unit.

Therefore, the research allows us to point out possibilities for further studies in the categories highlighted here, from which thematic areas on the knowledge of Mathematics teachers immersed in the context of continuing education for meaningful learning are expanded, with the practice of research as an articulating axis for the adult-teacher-apprentice to develop professionally. Therefore, it is increasingly necessary to research, discuss and reflect on their training needs.

Authors' Contributions: Alves, A. O.: conception and design, acquisition of data, analysis and interpretation of data, drafting the article, critical review of important intellectual content; Lima, I. P.: conception and design, acquisition of data, analysis and interpretation of data, drafting the article, critical review of important intellectual content; Lima e Silva, J. F.: conception and design, acquisition of data, analysis and interpretation of data, drafting the article, critical review of important intellectual content. All authors have read and approved the final version of the manuscript.

Ethics Approval: Not applicable.

Acknowledgments: Not applicable.

\section{REFERENCES}

Alves, J. F. (2004). Teacher education and school practice: Dilemmas and perspectives for teaching Mathematics with research. [Dissertation]. Pontifical Catholic University of Campinas.

Ausubel, D. P. (2003). The acquisition and retention of knowledge: A cognitive view. Dordrecht: Kluwer Academic Publishers.

Ausubel, D. P. (2003). Aquisição e retenção de conhecimentos: Uma perspectiva cognitiva. Lisboa: Plátano Edições Técnicas. Translate to Portuguese of the acquisition and retention of knowledge: a cognitive view. (2000). Kluwer Academic Publishers. IBSN 972-707-364-6.

Barbosa, J. (org) (1998). Reflections on the multi-referential approach. São Carlos: UFSCAR.

Barreto, M. C. et al. (2013). The foundations of Activity Theory in the organization of Mathematics teaching. In: The formation of Mathematics teachers under different theoretical perspectives. Teresina: EDUFPI, 2013. p. 59-82.

Ben-chaim, D. \& Bat-shevailany, Y. (2008). Authentic Investigative Activities for the Teaching of Ratio and Proportion in the Training of Mathematics Teachers for Elementary and High School Levels. Bolema, v.21, n.31, p.125-159.

Bertini, L. F. (2009). Sharing knowledge in mathematics teaching in the early grades: A teacher in the context of investigative tasks. [Dissertation]. Masters Federal University of São Carlos. 
BRASIL. (1996). Law of Directives and Bases of National Education. Federal Law number 9394.

Camelo, Z. B. (2020). Pedagogical technological knowledge and content in the training of spatial geometry teacher. [Dissertation]. Masters State University of Ceará.

D’Ambrósio, U. (2009). Mathematics Education: From theory to practice. 17 ed. Campinas, SP: Papirus Editora.

Demo, P. (2002). Educate through research. 5 ed. Campinas: Autores Associados.

Demo, P. (2008). Participant research, knowing how to think and intervene together. Brasília: Liber Livro.

Fabrina, C. \& Albernaz, R. M. (2010). Mathematics Teacher: knowledge in moving training. INTERthesis Magazine, v. 07, n. 01, p. 302-323.

Fiorentini, D. \& Castro, F. C. de. (2003). Becoming a Mathematics Teacher: The Case of Allan in Teaching Practice and Supervised Internship, In: FIORENTINI, D. (org.) Mathematics teacher education: exploring new paths with different perspectives. Campinas, SP: Mercado das Letras.

Freire, P. (2011). Pedagogy of autonomy: knowledge necessary for educational practice. 43. ed. São Paulo: Paz e Terra. Freire, P. (2011). Pedagogy of the Oppressed. 50. ed. São Paulo: Paz e Terra.

Kincheloe, J. L. \& Berry, K. S. (2007). Education research: conceptualizing bricolage. Porto Alegre: ArtMed.

Gauthier, C. et al. (2006). For a Theory of Pedagogy: Contemporary research on teaching knowledge. 2 ed. ljuí: Unijuí. Moreira, M. A. (2012). Meaningful learning: Theory and complementary texts. São Paulo: Livraria Editora da Física.

Neto, O. Z. (2009). Time and knowledge: The constitution of the experienced teacher in mathematics. [Thesis]. São Paulo State University, Literature of Araraquara and Federal University of Rondônia.

Nóbrega-Therrien, S. M. \& Therrien, J. (2010). The state of the question: Theoretical-methodological contributions and reports of production in scientific works. In: FARIAS, Isabel Sabino de; NUNES, João Batista de Carvalho; NÓBREGATHERRIEN, Silvia Maria. Scientific Research for Beginners: Walking the Maze. Fortaleza, EdUECE.

Pimenta, S. G. \& Ghedin, E. (Org). (2002). Reflective Professor in Brazil: Genesis and critique of a concept. São Paulo: Cortez.

PONTE, João Pedro da. (1997). Perspectives of professional development of mathematics teachers in a process of curriculum change. In: Ponte P. et al. Professional development of mathematics teachers - what training? Lisboa: Sociedade Portuguesa de Ciências da Educação.

Ponte, J. P. da. (2009). Research on the Mathematics teacher: Problems and perspectives. I SIPEM - International Seminar on Research in Mathematics Education. São Paulo, Brasil.

Silva, R. V. da. (2016). Articulation of teaching and research in teaching practice: experiences and meanings of teachers in the teaching courses of the Federal Institute of Education of Piaui. [Dissertation]. Masters Federal University of Piaui.

Silvano, A. M. (2019). Teacher knowledge and meaningful learning in initial teacher education using interactive digital interfaces. [Thesis]. State University of Ceará.

Sousa, C. O. (2018). Continuing teacher education and the concept of space: Contributions from the Meaningful Learning theory. [Dissertation]. Masters State University of Ceará.

Valente, W. R. (2008). Who are we Mathematics teachers? Cedes Journal, v.28, n.74, p.11-23.

Wichnoski, P. (2017). Metasearch in mathematical research: an analysis from the abstracts. Mathematics Education Research Magazine, v.19, n.2, p.161-178.

Received: 25 August 2021 | Accepted: 22 November 2021 | Published: 29 December 2021 